\title{
Research on the Influence Mechanism of Consumers' Purchase Intention of Electric Vehicles Based on Perceived Endorsement: A Case Study of Chinese Electric Vehicle Start-Ups
}

\author{
Yong Zang ${ }^{1}{ }^{\mathbb{D}}$, Jue Qian ${ }^{1, *}$ and Qianling Jiang ${ }^{2, *} \mathbb{( D}$ \\ 1 College of Arts and Design, Zhejiang A\&F University, Hangzhou 311300, China; 20200017@zafu.edu.cn \\ 2 School of Design, Jiangnan University, Wuxi 214122, China \\ * Correspondence: 20200018@zafu.edu.cn (J.Q.); magicjq1@gmail.com (Q.J.)
}

check for

updates

Citation: Zang, Y.; Qian, J.; Jiang, Q.

Research on the Influence

Mechanism of Consumers' Purchase Intention of Electric Vehicles Based on Perceived Endorsement: A Case Study of Chinese Electric Vehicle Start-Ups. World Electr. Veh. J. 2022, 13, 19. https://doi.org/10.3390/ wevj13010019

Academic Editor: Zhenhong Lin

Received: 9 October 2021

Accepted: 7 January 2022

Published: 9 January 2022

Publisher's Note: MDPI stays neutral with regard to jurisdictional claims in published maps and institutional affiliations.

Copyright: (c) 2022 by the authors. Licensee MDPI, Basel, Switzerland. This article is an open access article distributed under the terms and conditions of the Creative Commons Attribution (CC BY) license (https:/ / creativecommons.org/licenses/by/ $4.0 /)$.

\begin{abstract}
During the last decade, a number of electric vehicle start-ups have emerged in China. Although there have been quite a lot of studies on consumers' purchase decision of electric vehicles, it is not common in the case of electric vehicle start-ups. This paper puts forward the concept of perceived endorsement and discusses the relationship among perceived benefit, perceived risk, range anxiety, attitude and consumers' purchase intention and establishes a theoretical model of consumers' purchase intention towards electric vehicles from start-ups. A structural equation model was used to test the research model and the hypotheses of the model. The results indicate that perceived endorsement has a significant positive influence on perceived benefit and attitude, which then affects consumers' purchase intention, but range anxiety and perceived risk have no impact on purchase intention.
\end{abstract}

Keywords: perceived endorsement; Chinese electric vehicle start-ups; purchase intention

\section{Introduction}

The oil crisis and excessive carbon emissions are both considered to be the most urgent challenges of the current generation [1,2]. Emissions from transportation are the main cause of climate change [3]. In China, transportation is the fastest growing sector in terms of both oil demand and greenhouse gas emissions [4]. The rapid growth of private cars leads to the continuous growth of China's oil demand, which has been widely considered as the main factor affecting future oil supply and price and also the main contributor to China's greenhouse gas emissions [4]. There is no doubt that in the near future, the transportation sector will play a leading role in China's emission inventory. According to the research of $\mathrm{Hu}$ et al. in 2010, it is estimated that China's annual oil demand for road traffic will reach 363 million tons by 2030 [5]. Especially with the continuous improvement of Chinese people's income level, people's demand for cars is also increasing [6]. The development of electric vehicles is driven by the increasing demand of automobile consumption, the global energy shortage and the worsening ecological environment crisis. Furthermore, electric vehicles are one of the internationally recognized solutions to environmental problems as they generate zero direct emissions and reduce dependence on oil [7,8]. An electric vehicle is a vehicle driven only by electricity. The power source is mainly provided by rechargeable batteries inside the vehicle, which can greatly reduce greenhouse gas emissions $[9,10]$. Electric vehicles have attracted the attention of more and more countries [11], and are considered to be the main force of the future transportation system [12]. Many countries have formulated corresponding goals and policies [13], and China is no exception [14]. China has become the world's largest market for electric vehicles due to its national policies [11]. The global automobile manufacturers also began to develop their own electric vehicles in line with the times [15]. It is estimated that by 2035, there will be more than 145 million electric vehicles in the world [16]. A test in New York shows that electric 
vehicles play an important role in reducing urban air pollution [17] and can reduce carbon emissions by $20 \%$ [18].

In addition to environmental protection, the main environmental disturbance forces are: energy pressure and pressure from the market share. In the past three decades in the Chinese auto market, foreign capital has still dominated joint ventures with brand recognition and core technologies, claiming most of the profits. Obviously, in the electric vehicle industry, the gap between China and foreign brands is not obvious, and China even has a more complete industrial chain. In addition, China is the world's largest automobile market. The development of domestic electric vehicle brands is a chance for the Chinese auto industry to overtake competitors, and the next five to ten years is a critical period.

Tesla has successfully subverted the traditional automobile industry, launching popular products repeatedly, and its market value has increased to more than USD 50 billion. The redefinition of the electric vehicle market has aroused the interest of many people [19], and many Chinese entrepreneurs recognized the opportunity to replicate this successful path. Therefore, in recent years, a number of electric vehicle start-ups have emerged in China. In this study, electric vehicle start-ups refer to Chinese battery electric vehicle brands that have been established and developed rapidly in recent years, including NIO, XPENG, etc., which are different from traditional automakers.

Therefore, whether from the perspective of environmental protection and clean energy sources or from the perspective of the development of the national automobile industry, the positive development of electric vehicle start-ups is of great significance. Especially regarding automobile start-ups, studies have shown that consumers are more likely to choose automobile brands that have greater popularity. Brands with a long history will bring the user a sense of security and trust [20]. As an industry strongly supported by the Chinese government, the development and manufacturing of new energy vehicles has received a lot of policy preferences, including tax cuts for enterprises and tax exemptions for consumers to stimulate the development of the new energy vehicle industry. This also represents the country's attention to this area. As a result, many new electric car brands have emerged. To some extent, it also represents the way and means of China's economic development. The emergence of new forces in car manufacturing also threatens traditional car enterprises, and so they will invest more in the research and development of new models, especially new energy models, which stimulates the overall development of the industry.

In addition, traditional brands have obvious technical advantages in terms of fuel automobile production and manufacturing. However, in the field of battery electric vehicles, electric vehicle start-ups and traditional automobile brands are almost at the same starting line in terms of technology reserves, and the current electric vehicle start-ups are almost all electric vehicle manufacturers, which presents a new opportunity for electric vehicles to shorten the gap between China and foreign advanced automobile industry and gradually realize a leading position among competitors [21]. Therefore, it is very necessary to understand the factors of consumers' purchase of electric vehicles by taking electric vehicle start-ups as the research object for the development of electric vehicle start-ups. In addition to the efforts of global governments and automobile manufacturers, consumers are also the key to the promotion of electric vehicles. If more consumers choose electric vehicles, the reduction in oil consumption and $\mathrm{CO}_{2}$ emissions would be more significant [22]. At the key point of the transition from traditional vehicles to electric vehicles, consumers' purchase of electric vehicles will have a huge impact on the promotion of electric vehicles and the development of the entire industry. Therefore, it is necessary to understand why consumers choose to buy electric vehicles.

It is worth noting that the electric vehicles studied and discussed in this study are pure electric four-wheel cars produced by newly emerging electric car manufacturers. We did not include hybrid cars, hydrogen vehicles or two-wheeled electric vehicles. 


\section{Literature Review and Research Hypotheses}

Many scholars have conducted in-depth research on the factors that affect consumers' purchase intention towards electric vehicles from different perspectives. Ewing et al. found that price, performance, using cost and time cost are the key factors affecting consumers' adoption of electric vehicles [23]. At the present stage, quite a lot of consumers still have insufficient knowledge about the technology used by electric vehicles, the overall impact on the environment and the cost of ownership of electric vehicles $[24,25]$. This is one of the reasons why electric vehicles have not been widely accepted. Another barrier is the range ability of electric vehicles [26], so a considerable number of potential consumers prefer plug-in hybrid vehicles as alternatives [27]. If the endurance problem were to be solved, it would improve consumers' adoption of electric vehicles [28]. Zhang et al. found that the purchase decisions of private car owners in Nanjing, China, were mainly affected by purchase pressure (friends' influence, legal or regulatory requirements, tax incentives, etc.) and product attractiveness [29]. There are many factors that affect consumers' purchase intention towards electric vehicles. In addition to the above factors, this study proposes a hypothesis model including perceived endorsement, range anxiety, perceived benefit, perceived risk, attitude and purchase intention according to the special attributes of electric vehicle start-ups. The hypotheses are described as below.

\subsection{Purchase Intention and Attitude}

Consumers' purchase intention and attitude have been discussed in many models, including the TRA [30], the TPB [31,32] and the TAM [33]. The basic assumption of TRA (theory of reasoned action) [30] is that humans are rational and will consider the meaning and consequences of their behaviors by synthesizing all kinds of information before making a decision, and points out that any factor needs to affect user behaviors through attitude and subjective norms. Ajzen [31,32] added perceived behavior control on the basis of the reasoned action theory and proposed the TPB (theory of planned behavior). Davis [33] developed TAM (technology acceptance model) to study users' acceptance of information systems based on the theory of reasoned action, which posists that user behavior is mainly affected by attitude and usefulness. In these models, attitude is interpreted as an individual's internal experience that affects consumers' purchase intention, while purchase intention is consumers' tendency to take action [31]. In this study, it is explained that consumers' attitude towards electric vehicles has an impact on their purchase intention. Therefore, this study hypothesizes that:

Hypothesis 1 (H1). Consumers' attitude towards electric vehicles has a significant positive correlation with their purchase intention.

\subsection{Perceived Benefits}

For consumers, the value perception of products and services is one of the important factors determining consumers' decision-making behavior [34]. Perceived benefit is the perceived possibility of positive results after taking action [35], which is a kind of cognitive emotion and has a positive impact on consumers' decision-making and behavior [36]. Many studies have highlighted the consumers' perceived benefits of electric vehicles from both economic and non-economic perspectives. In terms of economic aspects, the purchase subsidy of electric vehicles is very high $[37,38]$. At the same time, the nonexistent fuel consumption of electric vehicles and better after-sales service of manufacturers has also become one of the reasons for consumers to choose electric vehicles. In terms of noneconomic aspects, the nonexistent fuel consumption of electric vehicles represents their contribution to the environment [39]. At the same time, electric vehicles also have the advantages of silence, high technology, acceleration ability and stability [40]. Perceived benefit is one of the important reasons that affect consumers' purchase intention towards electric vehicles [41]. Therefore, this study hypothesizes that: 
Hypothesis 2 (H2). Consumers' perceived benefit of electric vehicles has a significant positive correlation with their purchase intention.

\subsection{Perceived Risk}

Perceived risk was firstly proposed in psychological research, referring to the expected negative effects perceived by consumers when they buy a specific product [42]. Due to the recentness of electric vehicles, many consumers still have prejudice against them [43], with concerns about factors, such as safety [44], reliability [45], battery life [46], etc., which are factors interring with consumers' decision to buy electric vehicles. The less consumers know about electric vehicles, the greater the prejudice and the greater the negative impact. In addition, consumers are not only affected by perceived benefits but also by perceived risks when they make decisions and take actions. Before making the final decision, consumers will comprehensively consider the risks and benefits to find the optimal solution [47]. Therefore, this study hypothesizes that:

Hypothesis 3 (H3). Consumers' perceived risk of electric vehicles has a significant negative correlation with their purchase intention.

Hypothesis 4 (H4). Consumers' perceived risk of electric vehicles has a significant negative correlation with their attitude.

\subsection{Range Anxiety}

Range anxiety refers to the worry that the vehicle owner or driver thinks that the vehicle does not have enough range ability to reach its destination and breaks down on the road. Although it is of far-reaching significance to use electric vehicles to replace traditional fuel-fueled vehicles, the battery capacity and range ability of electric vehicles are still very limited [48]. In addition, for electric vehicle users, besides the price of electric vehicles, the most important thing is the convenience of charging services during the journey [49]. The limitation of electric vehicle battery capacity and the lack of charging infrastructure are important reasons for range anxiety [50]. Therefore, this study hypothesizes that:

Hypothesis 5 (H5). Consumers' range anxiety of electric vehicles has a significant negative correlation with their perceived risk.

\subsection{Perceived Endorsement}

The term "endorsement" originates from the bank bill business, which originally referred to a kind of ancillary bill behavior, in which the payee signs and makes necessary records on the bill for the purpose of transferring the rights of the bill. Later, "endorsement" was endowed with the meaning of "confirmation, agreement and support", which can be understood as support provided by an influential third party, which makes the endorsed person or thing more credible and reliable. Dean pointed out that "endorsement" has an external implication for consumers, which is usually used by consumers to judge product reliability and attributes. There is a significant amount of literature indicating that "endorsement" has an effect on consumers' behavior [51]. Fireworker et al.'s research points out that early endorsement is mainly character endorsement, which can be divided into three types: expert endorsement, celebrity endorsement and typical consumer endorsement [52]. Expert refers to those individual, group or organization who have certain experience, knowledge or training, and specific knowledge that is superior to those who can be understood by the general public, such as scientists in the field of battery technology and autonomous driving. Celebrity refers to an individual who is well known to all, such as actors, athletes, etc. Celebrities usually have a certain achievement in their own profession field. Typical consumers refer to those who has no special expert knowledge beyond normal use of the product [52]. In addition to the above research, most academic research on endorsement focuses on the effect of endorsement in advertising, or the influence of endorsement type on different products [53], and its influence on changes in consumers' purchase behavior and attitude [54]. In recent years, many brands have begun to quote the endorsement of an 
impartial third-party group in their advertisements [55]. Some studies have also begun to focus on the research on consumers' attitudes and purchase behaviors as influence by a third-party group endorsement [51,56,57].

By searching "endorsement", "new energy vehicle", and" electric vehicle" as keywords on the Internet, we found that endorsement descriptions of this field from news and media include: Internet giant endorsement, government endorsement, policy endorsement, technology endorsement, expert endorsement, etc. According to the research object of this study, "electric vehicles start-ups", researchers conducted semi-structured interviews with five owners of electric vehicles from start-ups to clarify the composition of consumers' perceived endorsement. The information of five respondents is shown in Table 1. The results of the interview showed that all the five owners felt government endorsement and perceived government endorsement showed their recognition of electric vehicles' role from a nation perspective. It is believed that China's electric vehicle industry will be at the international leading level and have industrial initiative. All five owners felt the endorsement of the policy and the perception of the policy endorsement was that China would continue to promote preferential subsidies for electric vehicles, giving them priority in obtaining license plates and other policies. Two of the owners were influenced by the endorsement of the third-party group, and they chose their cars based on a video from the third-party evaluation organization. One of the owners felt that he was influenced by the endorsement of the entrepreneur [58]. He believed that the founder of the brand from which he bought his car was a continuous entrepreneur and had achieved success, so he had trust in the brand. One of the owners thought that China's advanced battery technology and complete electric vehicle supply chain were important contributors to his purchase. This study believes that he was not only influenced by the endorsement of technology but also the identity of national capacity. All five car owners said that the most important form of endorsement, whether it is an entrepreneur endorsement, technology endorsement or third-party group endorsement, is the generation of brand trust. Therefore, brand trust is an important part of the perceived endorsement of electric vehicles manufactured by start-ups. In addition, this also includes perceived policies and national identity. Therefore, this study determined brand trust, perceived policy and national identity as the three dimensions of perceived endorsement for further research.

Table 1. Basic information of respondents.

\begin{tabular}{cccc}
\hline Gender & Age & Brand & Time of Usage \\
\hline Male & 30 & Tesla & 3 years \\
\hline Male & 29 & Nio & 2 years \\
\hline Male & 30 & Nio & 2 years \\
\hline Female & 27 & Xpeng & 1 year \\
\hline Female & 30 & Tesla & 1 year \\
\hline
\end{tabular}

\subsubsection{Brand Trust}

Trust is one of the factors that need to be considered when explaining consumers behavior intention, and it plays an important role in the case of uncertainty and perceived risk [59]. Brand trust refers to the relationship between consumers' perception of a product or service quality and the manufacturers' brand and reputation [60]. The higher the consumers perceive the quality of brand products, the higher their trust in the brand, and the lower their perceived uncertainty and risk. Most of the research on brand trust comes from the field of food [59,61], business [62,63], online media [64-66], etc. As the electric vehicle industry is an emerging industry, most of the manufacturers or vehicle types are not well-known, except for Tesla and some well-known Chinese electric vehicles start-ups. However, this study believes that brand trust has an impact on consumers and 
can eliminate perceived uncertainty and risk [59]. At the same time, brand trust plays a part in the interests of consumers.

\subsubsection{Perception of Policy}

Irwin et al. pointed out that policies affect the validation of new technologies [67], while Flynn et al. mentioned in their research that policies affect the acceptance of products and technologies [68]. For the new energy vehicle market, China has put forward many environmental policies, such as subsidies for the purchase of electric vehicles and purchase tax remission. The research of Peters and others shows that financial incentives are an important reason that consumers buy electric vehicles [69]. Gallagher et al. and Chandra et al. found that tax remission increases the adoption rate of hybrid vehicles $[70,71]$.

\subsubsection{National Identity}

Tang et al. said in their research that when consumers mention a country, it is always associated with certain types of products, such as French perfume, Swiss watches, Japanese household appliances, etc. [58]. They also pointed out that countries can use this thinking to their own absolute advantages to establish excellent brand image for their own brands in the international market [58]. In addition, some studies have pointed out that the establishment of a brand requires excellent products and is also inseparable from strong national endorsement [72]. From the perspective of marketing, there are significant differences in the level of national identity among different countries [73], which is also reflected in the phenomenon of consumers' high preference for their own products in some countries [74]. All these studies show that national capacity identity can affect consumers' attitude.

Based on the above three dimensions, this study hypothesizes that:

Hypothesis 6 (H6). Consumers' perceived endorsement of electric vehicles has a significant negative correlation with their mileage anxiety.

Hypothesis 7 (H7). Consumers' perceived endorsement of electric vehicles has a significant positive correlation with their attitude.

Hypothesis 8 (H8). Consumers' perceived endorsement of electric vehicles has a significant positive correlation with their perceived benefits.

\subsection{Theoretical Model}

This study fully considers the characteristics of electric vehicle start-ups and uses the previous research technology methods and research results for reference to construct the model of consumers' purchase intention with six dimensions: perceived endorsement, range anxiety, perceived risk, perceived benefit, attitude and purchase intention. Eight related hypotheses are proposed. The model is shown in Figure 1.

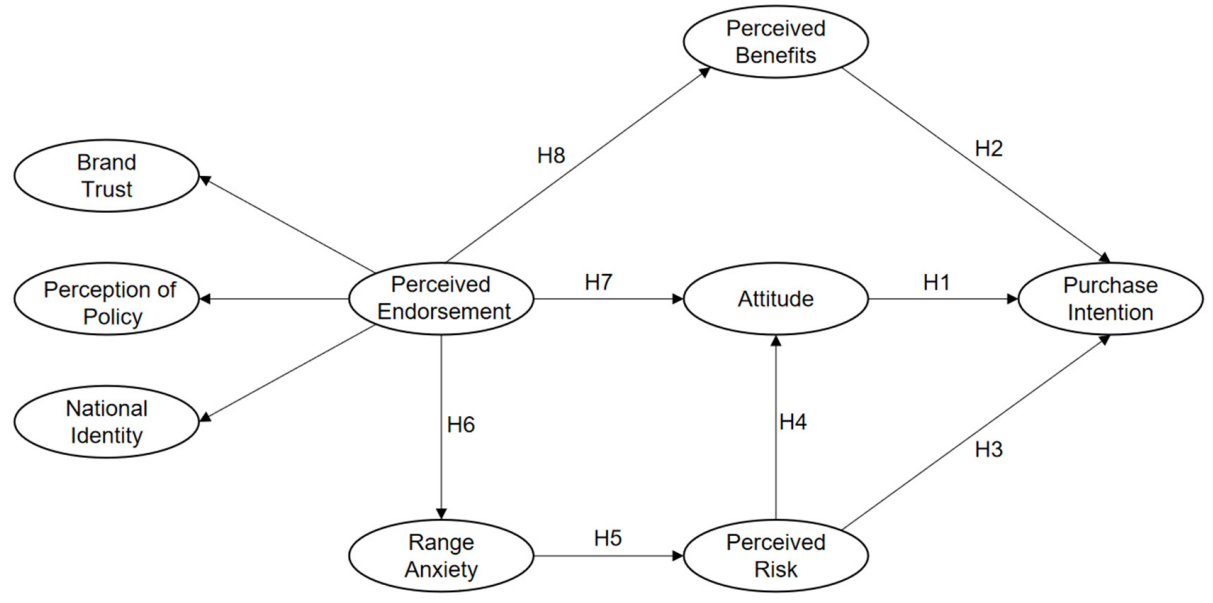

Figure 1. Research model. Source: author. 


\section{Research Design and Methods}

\subsection{Questionnaire Design}

In order to ensure the reliability of the study, the scales used in this study are all derived from mature scales that have been verified in the relevant literature [75-82]. The scales in the literature were adjusted according to the characteristics of the subject of this study so as to form the final questionnaire. The final questionnaire is divided into two parts: the first part collects the basic information of users; the second part is the behavior measurement of the subjects, as shown in Table 2.

Table 2. Questionnaire design and literature source.

\begin{tabular}{|c|c|c|c|}
\hline Latent Variable & Coding & Item & Source \\
\hline \multirow{3}{*}{ Perceived Benefits } & PB1 & $\begin{array}{l}\text { The relationship between the quality and price of } \\
\text { electric vehicles from newly emerging electric car } \\
\text { manufacturers is appropriate. }\end{array}$ & \multirow{3}{*}[75,76]{} \\
\hline & PB2 & $\begin{array}{l}\text { The pollution and energy consumption of electric } \\
\text { vehicles from newly emerging electric car } \\
\text { manufacturers are lower. }\end{array}$ & \\
\hline & PB3 & $\begin{array}{l}\text { Electric vehicles from newly emerging electric car } \\
\text { manufacturers are easier to license. }\end{array}$ & \\
\hline \multirow{3}{*}{ Perceived Risk } & PR1 & $\begin{array}{l}\text { I'm worried about the low-value preservation rate of } \\
\text { electric vehicles from new brands. }\end{array}$ & \multirow{3}{*}{ [77] } \\
\hline & PR2 & $\begin{array}{l}\text { I can't feel } 100 \% \text { safe when I'm driving an electric car } \\
\text { from a newly emerging electric car manufacturer. }\end{array}$ & \\
\hline & PR3 & $\begin{array}{l}\text { I'm worried that my family and friends don't } \\
\text { understand why I'm buying new brands of } \\
\text { electric cars. }\end{array}$ & \\
\hline \multirow{3}{*}{ Attitude } & AT1 & $\begin{array}{l}\text { For me, it's right to use an electric car from a newly } \\
\text { emerging electric car manufacturer. }\end{array}$ & \multirow{3}{*}{ [78] } \\
\hline & AT2 & $\begin{array}{l}\text { For me, it's wise to use an electric car from a newly } \\
\text { emerging electric car manufacturer. }\end{array}$ & \\
\hline & AT3 & $\begin{array}{l}\text { I'm interested in electric cars from newly emerging } \\
\text { electric car manufacturers. }\end{array}$ & \\
\hline \multirow{3}{*}{ Brand Trust } & BT1 & $\begin{array}{l}\text { I believe in the quality of the brand (including product } \\
\text { quality and service quality). }\end{array}$ & \multirow{3}{*}[78,79]{} \\
\hline & BT2 & $\begin{array}{l}\text { It's a safe choice to buy electric cars from newly } \\
\text { emerging electric car manufacturers. }\end{array}$ & \\
\hline & BT3 & I am sure that the brand I know or buy is reliable. & \\
\hline \multirow{2}{*}{ Perception of Policy } & PP1 & $\begin{array}{l}\text { I think the government's subsidy policy for the } \\
\text { purchase of electric vehicles is enough. }\end{array}$ & \multirow{2}{*}{ [77] } \\
\hline & PP2 & $\begin{array}{l}\text { I am very clear about the government's subsidy policy } \\
\text { for the purchase of electric vehicles. }\end{array}$ & \\
\hline \multirow{3}{*}{ Range Anxiety } & RA1 & $\begin{array}{l}\text { When I use an electric car from newly emerging } \\
\text { electric car manufacturers, I worry about the mileage } \\
\text { of the electric car. }\end{array}$ & \multirow{3}{*}{ [80] } \\
\hline & RA2 & $\begin{array}{l}\text { When I use an electric car from a newly emerging } \\
\text { electric car manufacturer, I worry that it will be very } \\
\text { difficult to find a charging point. }\end{array}$ & \\
\hline & RA3 & $\begin{array}{l}\text { When I use an electric car from a newly emerging } \\
\text { electric car manufacturers, I dare not use it for a long } \\
\text { distance. }\end{array}$ & \\
\hline
\end{tabular}


Table 2. Cont.

\begin{tabular}{lll}
\hline Latent Variable & Coding & Item \\
\hline NI1 & $\begin{array}{l}\text { I believe that China's electric vehicle industry will } \\
\text { become more and more powerful. }\end{array}$ \\
\cline { 2 - 3 } National Identity & NI3 & $\begin{array}{l}\text { I have confidence in the development of China's } \\
\text { automobile industry. }\end{array}$ \\
\hline PI1 & $\begin{array}{l}\text { I have confidence that China will be the leading and } \\
\text { controlling power of the electric vehicle industry. }\end{array}$ \\
\cline { 2 - 3 } & PI2 & $\begin{array}{l}\text { An electric cars from a newly emerging electric car } \\
\text { manufacturer is the best choice for me. }\end{array}$ \\
\cline { 2 - 4 } & $\begin{array}{l}\text { The next time I change cars, I will give priority to } \\
\text { electric cars from newly emerging electric car } \\
\text { manufacturers. }\end{array}$ \\
\hline PI3 & $\begin{array}{l}\text { I'd like electric vehicle stystems to be introdruced to } \\
\text { other man-made vehicles. }\end{array}$ \\
\hline
\end{tabular}

\subsection{Data Collection}

A total of 326 questionnaires were collected, 10 times more than the number of analysis items (23). Therefore, the sample size met the requirements of the SEM [82]. The data were collected from online sources, with a total of 326 copies. The respondents were all from China. The basic information of the subjects is shown in Table 3.

Table 3. Basic data of the respondents.

\begin{tabular}{llll}
\hline Sample & Category & Number & Percentage \\
\hline \multirow{2}{*}{ Gender } & Male & 182 & $55.8 \%$ \\
& Female & 144 & $44.2 \%$ \\
\hline \multirow{2}{*}{ Marital status } & Married & 193 & $59.2 \%$ \\
& Unmarried & 133 & $40.8 \%$ \\
\hline \multirow{3}{*}{ Age } & $18-25$ & 140 & $42.9 \%$ \\
& $26-34$ & 104 & $31.9 \%$ \\
& $35-54$ & 66 & $20.2 \%$ \\
Education & $55-64$ & 16 & $4.9 \%$ \\
\hline \multirow{5}{*}{ Occupation } & High school or technical & 51 & $15.6 \%$ \\
& secondary school and below & & $72.7 \%$ \\
& Undergraduate or junior college & 237 & $11.7 \%$ \\
\hline Is there a car license limitation & Graduate and above & 38 & $30.7 \%$ \\
policy in the city you live in? & Student & 100 & $31.0 \%$ \\
\hline
\end{tabular}

\section{Data Analysis}

\subsection{Exploratory Factor Analysis}

In this study, exploratory factor analysis (EFA) was used to verify unidimensionality to confirm that the items we modified according to the maturity scale belong to the same dimension. Principal component analysis (PCA) was used to extract new factors with eigenvalues greater than 1 . The results show that the KMO values (Kaiser-Meyer-Olkin, when the sum of the squares of simple correlation coefficients between all variables is 
far greater than the sum of the squares of partial correlation coefficients and the closer the $\mathrm{KMO}$ value is to 1 , the stronger the correlation between variables is, which indicates that the original variables are suitable for factor analysis.) of each construct were greater than 0.50 and the Bartlett spherical test significance was less than 0.05 , indicating that the data were suitable for exploratory factor analysis [83,84]. As result, all items of each construct were included in the extraction process of new factors, and only one new factor with an eigenvalue greater than 1 was extracted [85], indicating that all constructs have good one-dimensionality [86]. The results of the exploratory factor analysis are shown in Table 4 .

Table 4. Results of exploratory factor analysis.

\begin{tabular}{|c|c|c|c|c|c|c|c|}
\hline Construct & KMO & $\begin{array}{l}\text { Bartlett } \\
\text { Sphere Test }\end{array}$ & Item & Commonality & $\begin{array}{l}\text { Factor } \\
\text { Loading }\end{array}$ & Eigenvalue & $\begin{array}{l}\text { Total } \\
\text { Variation } \\
\text { Explained \% }\end{array}$ \\
\hline \multirow{3}{*}{$\begin{array}{l}\text { Perceived } \\
\text { Benefits }\end{array}$} & \multirow{3}{*}{0.712} & \multirow{3}{*}{0.000} & PB1 & 0.697 & 0.835 & \multirow{3}{*}{2.161} & \multirow{3}{*}{$72.021 \%$} \\
\hline & & & PB2 & 0.727 & 0.853 & & \\
\hline & & & PB3 & 0.736 & 0.858 & & \\
\hline \multirow{3}{*}{ Perceived Risk } & \multirow{3}{*}{0.654} & \multirow{3}{*}{0.000} & PR1 & 0.650 & 0.806 & \multirow{3}{*}{1.814} & \multirow{3}{*}{$60.482 \%$} \\
\hline & & & PR2 & 0.624 & 0.790 & & \\
\hline & & & PR3 & 0.540 & 0.735 & & \\
\hline \multirow{3}{*}{ Attitude } & \multirow{3}{*}{0.729} & \multirow{3}{*}{0.000} & AT1 & 0.791 & 0.890 & \multirow{3}{*}{2.477} & \multirow{3}{*}{$82.557 \%$} \\
\hline & & & AT2 & 0.873 & 0.934 & & \\
\hline & & & AT3 & 0.813 & 0.901 & & \\
\hline \multirow{3}{*}{ Brand Trust } & \multirow{3}{*}{0.744} & \multirow{3}{*}{0.000} & BT1 & 0.832 & 0.912 & \multirow{3}{*}{2.461} & \multirow{3}{*}{$82.020 \%$} \\
\hline & & & BT2 & 0.838 & 0.915 & & \\
\hline & & & BT3 & 0.791 & 0.889 & & \\
\hline \multirow{3}{*}{ National Identity } & \multirow{3}{*}{0.714} & \multirow{3}{*}{0.000} & NI1 & 0.770 & 0.878 & \multirow{3}{*}{2.305} & \multirow{3}{*}{$76.840 \%$} \\
\hline & & & NI2 & 0.818 & 0.904 & & \\
\hline & & & NI3 & 0.717 & 0.847 & & \\
\hline \multirow{2}{*}{$\begin{array}{l}\text { Perception of } \\
\text { Policy }\end{array}$} & \multirow{2}{*}{0.500} & \multirow{2}{*}{0.000} & PP1 & 0.773 & 0.879 & \multirow{2}{*}{1.547} & \multirow{2}{*}{$77.349 \%$} \\
\hline & & & PP2 & 0.773 & 0.879 & & \\
\hline \multirow{3}{*}{ Range Anxiety } & \multirow{3}{*}{0.698} & \multirow{3}{*}{0.000} & RA1 & 0.696 & 0.834 & & \\
\hline & & & RA2 & 0.735 & 0.857 & 2.245 & $74.828 \%$ \\
\hline & & & RA3 & 0.813 & 0.902 & & \\
\hline & & & PI1 & 0.763 & 0.873 & & \\
\hline Purchase & 0.723 & 0.000 & PI2 & 0.845 & 0.919 & 2.389 & $79.632 \%$ \\
\hline & & & PI3 & 0.781 & 0.884 & & \\
\hline
\end{tabular}

\subsection{Confirmatory Factor Analysis}

In this study, confirmatory factor analysis (CFA) was used to verify whether the corresponding relationship between measurement factors and measurement items (scale items) was consistent with the researcher's prediction. The factor loading coefficient shows the correlation degree between the construct and the measurement item. Generally, the standardized factor loading coefficient is used for analysis. It can be seen from the table below that all the measurement items had a significant level of $0.001(p<0.001)$, and the standardized factor loading coefficient values were greater than 0.6 , which shows that there was a good correspondence between the construct and the measurement items, and the convergent validity of construct was good. The AVE values of each construct were all 
greater than 0.4 , and the $\mathrm{CR}$ values were all greater than 0.6 , which indicate that the data of this scale had good convergent validity. The results of the measurement model are shown in the following Table 5.

Table 5. The results of the measurement model.

\begin{tabular}{|c|c|c|c|c|c|c|c|c|}
\hline \multicolumn{7}{|c|}{ Factor Loading Coefficient Table } & \multirow{2}{*}{ AVE } & \multirow{2}{*}{ CR } \\
\hline Construct & Item & Unstd. & S.E. & Unstd./S.E. & $p$-Value & Std. & & \\
\hline \multirow{3}{*}{$\begin{array}{l}\text { Perceived } \\
\text { Benefits }\end{array}$} & PB1 & 1.000 & & & & 0.727 & \multirow{3}{*}{0.573} & \multirow{3}{*}{0.801} \\
\hline & PB2 & 1.004 & 0.083 & 12.096 & 0.000 & 0.718 & & \\
\hline & PB3 & 1.077 & 0.078 & 13.808 & 0.000 & 0.831 & & \\
\hline \multirow{3}{*}{$\begin{array}{l}\text { Perceived } \\
\text { Risk }\end{array}$} & PR1 & 1.000 & & & & 0.642 & \multirow{3}{*}{0.407} & \multirow{3}{*}{0.673} \\
\hline & PR2 & 1.040 & 0.126 & 8.254 & 0.000 & 0.646 & & \\
\hline & PR3 & 1.009 & 0.124 & 8.137 & 0.000 & 0.628 & & \\
\hline \multirow{3}{*}{ Attitude } & AT1 & 1.000 & & & & 0.826 & \multirow{3}{*}{0.746} & \multirow{3}{*}{0.898} \\
\hline & AT2 & 1.138 & 0.055 & 20.691 & 0.000 & 0.918 & & \\
\hline & AT3 & 1.008 & 0.055 & 18.327 & 0.000 & 0.842 & & \\
\hline \multirow{3}{*}{ Brand Trust } & BT1 & 1.000 & & & & 0.879 & \multirow{3}{*}{0.734} & \multirow{3}{*}{0.892} \\
\hline & BT2 & 0.938 & 0.045 & 20.844 & 0.000 & 0.860 & & \\
\hline & BT3 & 0.861 & 0.044 & 19.568 & 0.000 & 0.827 & & \\
\hline \multirow{3}{*}{$\begin{array}{l}\text { National } \\
\text { Identity }\end{array}$} & NI1 & 1.000 & & & & 0.804 & \multirow{3}{*}{0.655} & \multirow{3}{*}{0.850} \\
\hline & NI2 & 1.114 & 0.065 & 17.138 & 0.000 & 0.880 & & \\
\hline & NI3 & 0.995 & 0.070 & 14.214 & 0.000 & 0.745 & & \\
\hline \multirow{2}{*}{$\begin{array}{l}\text { Perception } \\
\text { of Policy }\end{array}$} & PP1 & 1.000 & & & & 0.705 & \multirow{2}{*}{0.554} & \multirow{2}{*}{0.713} \\
\hline & PP2 & 1.203 & 0.104 & 11.567 & 0.000 & 0.777 & & \\
\hline \multirow{3}{*}{$\begin{array}{l}\text { Range } \\
\text { Anxiety }\end{array}$} & RA1 & 1.000 & & & & 0.742 & \multirow{3}{*}{0.628} & \multirow{3}{*}{0.835} \\
\hline & RA2 & 1.076 & 0.081 & 13.284 & 0.000 & 0.775 & & \\
\hline & RA3 & 1.119 & 0.079 & 14.165 & 0.000 & 0.862 & & \\
\hline \multirow{3}{*}{$\begin{array}{l}\text { Purchase } \\
\text { Intention }\end{array}$} & PI1 & 1.000 & & & & 0.822 & \multirow{3}{*}{0.697} & \multirow{3}{*}{0.874} \\
\hline & PI2 & 1.012 & 0.055 & 18.400 & 0.000 & 0.872 & & \\
\hline & PI3 & 0.977 & 0.059 & 16.559 & 0.000 & 0.813 & & \\
\hline
\end{tabular}

According to the research of Fornell and Larcker [87], to meet the requirement of discriminant validity, the square root of the AVE value of each construct should be greater than the correlation coefficient of other factors. As shown in Table 6 below, the square roots of the AVE values of each construct, represented by the diagonal bold numbers in this study, are greater than the correlation coefficients between other variables, which proves that the discriminant validity of each construct is good. 
Table 6. Discriminant validity for the measurement model.

\begin{tabular}{|c|c|c|c|c|c|c|c|c|}
\hline & PB & PR & AT & BT & NI & PP & RA & PI \\
\hline Perceived Benefits & 0.757 & & & & & & & \\
\hline Perceived Risk & 0.438 & 0.638 & & & & & & \\
\hline Attitude & 0.665 & 0.388 & 0.864 & & & & & \\
\hline Brand Trust & 0.691 & 0.390 & 0.781 & 0.857 & & & & \\
\hline National Identity & 0.480 & 0.328 & 0.523 & 0.589 & 0.809 & & & \\
\hline Perception of Policy & 0.441 & 0.453 & 0.455 & 0.526 & 0.561 & 0.745 & & \\
\hline Range Anxiety & 0.377 & 0.385 & 0.329 & 0.301 & 0.539 & 0.526 & 0.793 & \\
\hline Purchase Intention & 0.621 & 0.330 & 0.701 & 0.725 & 0.581 & 0.534 & 0.414 & 0.835 \\
\hline
\end{tabular}

Note: the items on the diagonal on bold represent the square roots of the AVE.

\subsection{Structural Model Analysis}

According to the research architecture diagram, Amos 23.0 was used to analyze the path of each dimension. In order to test the direct effect and mediating effect, 2000 bootstrap calculations were used, with a confidence interval of $95 \%$, to measure whether the theoretical model and research hypotheses matched the data items analyzed. It is found that the model is feasible, as $\chi^{2} / \mathrm{df}$, RMSEA, CFI, IFI and SRMR were 2.870, 0.076, 0.912, 0.913 and 0.095 , respectively. All the fitting indexes met the recommended model fitting standard. In conclusion, the results of path analysis in this study met the acceptable standards.

In this study, the effect of each path in the model was tested. The standardized coefficient values are shown in Table 7, and the model analysis results are shown in Figure 2. The results show that: path coefficients of the influence of perceived risk on attitude and purchase intention are not significant, so $\mathrm{H} 3$ and $\mathrm{H} 4$ were not valid. Therefore, perceived risk does not have a direct impact on attitude and purchase intention, and all other path hypotheses are significant.

Table 7. Regression coefficient.

\begin{tabular}{|c|c|c|c|c|c|c|c|c|}
\hline DV & $\leftarrow$ & IV & Unstd & S.E. & Unstd./S.E. & $p$-Value & Std. & $\mathbf{R}^{2}$ \\
\hline Perceived Benefits & $\leftarrow$ & $\begin{array}{c}\text { Perceived } \\
\text { Endorsement }\end{array}$ & 1.344 & 0.160 & 8.400 & 0.000 & 0.892 & 0.795 \\
\hline Range Anxiety & $\leftarrow$ & $\begin{array}{c}\text { Perceived } \\
\text { Endorsement }\end{array}$ & 0.785 & 0.122 & 6.434 & 0.000 & 0.515 & 0.265 \\
\hline Perceived Risk & $\leftarrow$ & Range Anxiety & 0.505 & 0.077 & 6.558 & 0.000 & 0.544 & 0.296 \\
\hline \multirow[t]{2}{*}{ Attitude } & $\leftarrow$ & $\begin{array}{c}\text { Perceived } \\
\text { Endorsement }\end{array}$ & 1.497 & 1.167 & 1.283 & 0.000 & 0.892 & \multirow[t]{2}{*}{0.788} \\
\hline & $\leftarrow$ & Perceived Risk & -0.021 & 0.054 & -0.389 & 0.701 & -0.017 & \\
\hline \multirow{3}{*}{ Purchase Intention } & $\leftarrow$ & Perceived Risk & -0.005 & 0.060 & -0.083 & 0.938 & -0.004 & \multirow{3}{*}{0.707} \\
\hline & $\leftarrow$ & Attitude & 0.462 & 0.092 & 5.022 & 0.000 & 0.437 & \\
\hline & $\leftarrow$ & Perceived Benefits & 0.532 & 0.109 & 4.881 & 0.000 & 0.453 & \\
\hline
\end{tabular}




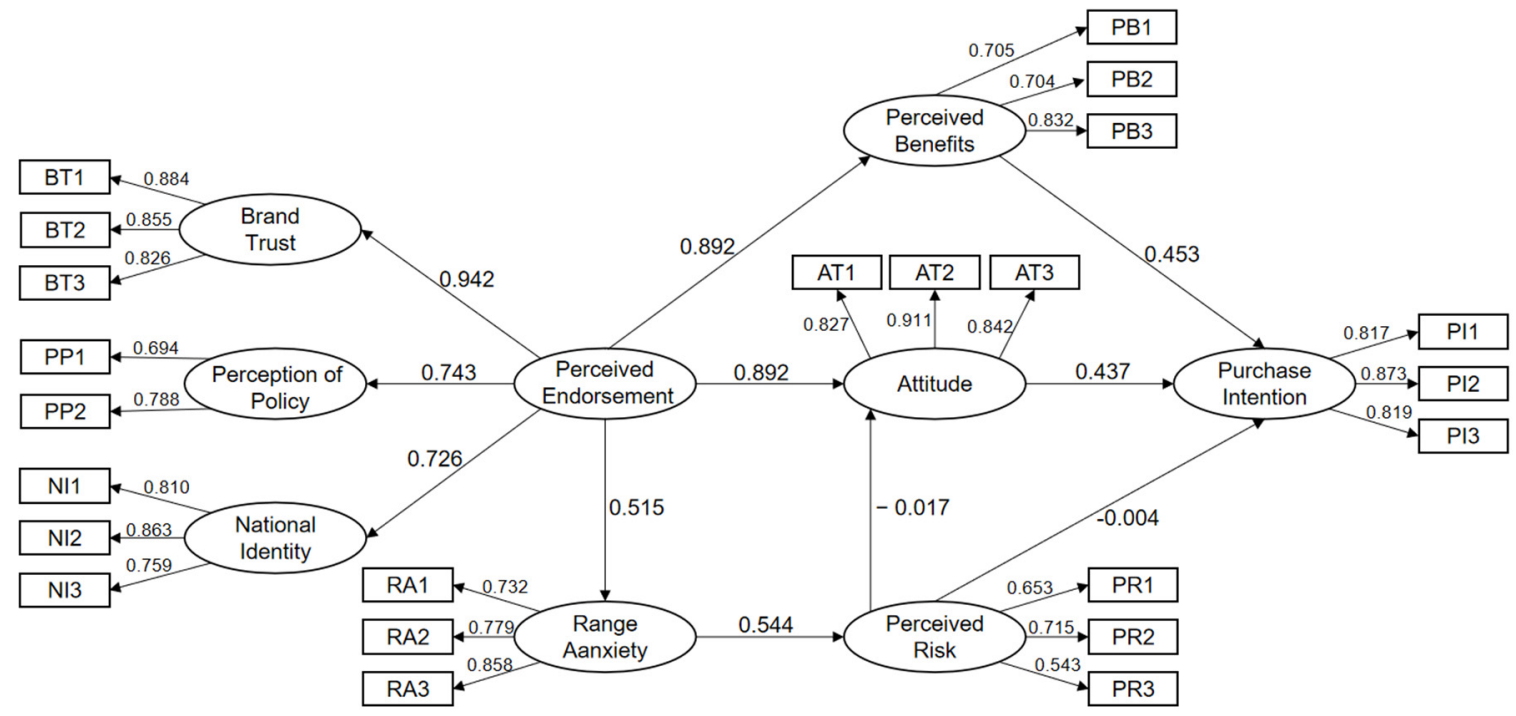

Figure 2. The influence between variables in the structural model. Source: author.

\section{Results and Discussion}

The results of the empirical analysis provide some key findings. Specific discussions are as follows:

$\mathrm{H} 1$ was valid, which means there is a significant positive correlation between attitude and consumers' purchase intention towards electric vehicles from start-ups. Consumers who show a more positive attitude towards using and buying electric vehicles from startups are more willing to buy them $[40,88]$. The direct effect of attitude on intention has been studied and demonstrated in the TRA [30], TPB [31,32] and TAM [33]. Therefore, attitude is a good predictor of consumers' purchasing decisions. $\mathrm{H} 2$ was valid, which means there is a significant positive correlation between perceived benefit and consumers' purchase intention towards electric vehicles from start-ups. This also indicates that consumers' perceived benefits directly affect consumers' intention to buy electric vehicles from startups. Consumers are aware that electric vehicles have the advantages of nonexistent fuel consumption, low pollution and a smooth operation compared with traditional internal combustion engine vehicles $[89,90]$ and have the policy advantages of easy registration and a higher subsidy for car purchase [14], as well as the advantage of a low cost. All these cause consumers to reconsider their decision to purchase electric vehicles due to environmental protection, oil price and other factors. Therefore, perceived benefit is a favorable predictor of consumers' purchasing decisions [91].

$\mathrm{H} 3$ and $\mathrm{H} 4$ were not valid, which means that perceived risk is not correlated with consumers' attitude and purchase intention towards electric vehicles from start-ups. According to Yang et al.'s research results, perceived risk does not affect consumers' attitude and purchase intention towards electric vehicles from start-ups, which is partly consistent with the results [92]. In view of this result, this study conducted another interview with the five car owners of vehicles manufactured by start-ups in the above interview. The five respondents all said that they perceived the risks of buying electric vehicles from start-ups, but they had determined to avoid outside influences in advance, and they had a considerable expectation of the risks and the ability to bear the risks. This may be related to the source of the sample of respondents in this study. The basic information about respondents shows that $58.3 \%$ of them live in cities with license plate limit policies. That is why they still chose an electric vehicle despite the perceived risks.

H5 was valid, which means that range anxiety has a significant positive correlation with consumers' perceived risk of electric vehicles from start-ups. It indicates that range anxiety will directly affect consumers' perceived risk of electric vehicles from start-ups. Range anxiety is a widely mentioned problem in the electric vehicle field [93,94], many start-ups in electric vehicle manufacturing are constantly expanding their battery capacity, 
accelerating the charging speed of batteries and increasing the number of charging stations to reduce consumers' range anxiety and thus reduce the degree of consumers' perceived risk. Therefore, range anxiety is a good predictor of consumers' perceived risk.

H6 was invalid, which indicates that perceived endorsement has no negative impact on users' range anxiety, and the data show that perceived endorsement increases users' range anxiety rather than reducing it. In the stage of user interviews, some users said that their purchase of electric vehicles was driven by governmental subsidies and preferential policy, suggesting that the government hopes to relieve users' inconvenience caused by the technological limitations of electric vehicles through polices and subsidies, which can indirectly and constantly hint that electric vehicle technology still has certain problems, which deepens users' range anxiety.

$\mathrm{H} 7$ and $\mathrm{H} 8$ were valid, indicating that there is a significant positive correlation between perceived endorsement and consumers' attitudes and perceived benefits towards electric vehicles. It indicates that perceived endorsement will directly affect consumers' attitudes and perceived benefits towards electric vehicles. According to the research of Erdem [95] et al., consumers are more willing to believe that famous brands will provide better quality assurance and high-quality service, which indicates that brand trust, a perceived endorsement dimension, improves users' perception of benefits of electric vehicles. The other two dimensions are perceived policy and national identity, which represent consumers' identification of China's vigorous development of electric vehicle industry. Consumers believe that China will increase preferential policies for electric vehicle purchases, support for electric vehicle brands and construction of charging stations. All these will affect consumers' attitudes, perceived benefits and range anxiety to some extent. Therefore, perceived endorsement is a favorable predictor of consumers' perceived benefits, attitudes and range anxiety.

\section{Conclusions and Suggestions}

The main contribution of this study is the establishment of a theoretical model of the influencing factors of consumers' purchase intention towards electric vehicles from start-ups from the perspective of the dimensions of perceived endorsement, perceived benefits, perceived risk, range anxiety, attitude and purchase intention. According to the path analysis in this study, perceived endorsement, perceived benefits and attitude towards electric vehicles from start-ups have direct or indirect influences on their purchase intention. At the same time, the conclusions of this study can be used as a reference for the Chinese government, consumers and relevant practitioners of start-ups in the electric vehicle industry to increase the sales of electric vehicles, so as to reduce transportation carbon emissions, abolish international energy constraints and improve the market share of domestic automobile brands.

The results show that: (1) consumers' attitudes and perceived benefits are important factors that influence consumers' purchase intention towards electric vehicles from startups; (2) perceived endorsements had significant positive effects on perceived benefits, range anxiety and attitude (3) Range anxiety significantly affected perceived risk, but perceived risk had no influence on attitude or purchase intention. (The results show that perceived endorsement plays an important role in influencing consumers' purchase intention towards electric vehicles from start-ups, and perceived endorsement influences consumers' purchase intention through influencing perceived benefits and attitude. At the same time, due to the particularity of China's license plate restriction policy, perceived risk and range anxiety are not the main factors affecting consumers' purchase of electric vehicles from start-ups. Based on the above results, the following suggestions are proposed:

- For the government: (1) the government should support the development of electric vehicle start-ups through appropriate endorsement, so as to avoid excessive endorsement resulting in consumers' perception about the underdeveloped technology of electric vehicles; (2) the government should continuously give consumers preferential policies when they buy electric vehicles to increase the perceived benefits of consumers. 
- For the electric vehicle start-ups: (1) start-ups should strengthen the construction of brand trust to increase brand endorsement; (2) start-ups should avoid false publicity of data such as range ability and charging speed, which may not affect consumers' purchase intention but may affect consumers' brand trust.

Finally, this study also has some limitations, which can be continuously improved and deepened in follow-up research. In this study, respondents were mainly from developed coastal cities, and more than half of them lived in cities with a license plate limit policy. The sample representation was slightly insufficient. In addition, there are many factors that affect consumers' purchase of electric vehicles, such as environmental values, gender, vehicle use, etc., and some variables could be considered in future research to build a more comprehensive and reasonable research model.

Author Contributions: All the authors contributed to the design, development and analysis of the paper. All authors have read and agreed to the published version of the manuscript.

Funding: This research was funded by "Zhejiang A\&F University", grant number 2020FR026; “Ministry of Education of the People's Republic of China", grant number 21YJC760029.

Institutional Review Board Statement: Not applicable.

Informed Consent Statement: Not applicable.

Conflicts of Interest: The authors declare no conflict of interest.

\section{References}

1. Sang, Y.-N.; Bekhet, H.A. Modelling electric vehicle usage intentions: An empirical study in Malaysia. J. Clean. Prod. 2015, 92, 75-83. [CrossRef]

2. Li, L.; Cao, R.; Wei, K.; Wang, W.; Chen, L. Adapting climate change challenge: A new vulnerability assessment framework from the global perspective. J. Clean. Prod. 2019, 217, 216-224. [CrossRef]

3. Batur, I.; Bayram, I.S.; Koc, M. Impact assessment of supply-side and demand-side policies on energy consumption and $\mathrm{CO}_{2}$ emissions from urban passenger transportation: The case of Istanbul. J. Clean. Prod. 2019, 219, 391-410. [CrossRef]

4. Yan, X.; Crookes, R.J. Life cycle analysis of energy use and greenhouse gas emissions for road transportation fuels in China. Renew. Sustain. Energy Rev. 2009, 13, 2505-2514. [CrossRef]

5. He, K.B.; Huo, H.; Zhang, Q.; He, D.Q.; An, F.; Wang, M.; Walsh, M.P. Oil consumption and $\mathrm{CO}_{2}$ emissions in China's road transport: Current status, future trends, and policy implications. Energy Policy 2005, 33, 1499-1507. [CrossRef]

6. Sina. With the Continuous Improvement of Living Standards, People's Demand for Cars Continues to Increase. Available online: https:/ / cj.sina.com.cn/articles/view/6451924161/180908cc100100bawa (accessed on 7 January 2022).

7. Khidir ElTayeb, T. The examination on the drivers for green purchasing adoption among EMS 14001 certified companies in Malaysia. J. Manuf. Technol. Manag. 2010, 21, 206-225. [CrossRef]

8. Buekers, J.; Van Holderbeke, M.; Bierkens, J.; Panis, L. Health and environmental benefits related to electric vehicle introduction in EU countries. Transp. Res. Part D Transp. Environ. 2014, 33, 26-38. [CrossRef]

9. Ehsani, M.; Gao, Y.; Longo, S.; Ebrahimi, K.M. Modern Electric, Hybrid Electric, and Fuel Cell Vehicles; CRC press: Boca Raton, FL, USA, 2018.

10. Grunditz, E.A.; Thiringer, T. Performance analysis of current BEVs based on a comprehensive review of specifications. IEEE Trans. Transp. Electrif. 2016, 2, 270-289. [CrossRef]

11. Cazzola, P.; Gorner, M.; Schuitmaker, R.; Maroney, E. Global EV outlook 2016; International Energy Agency: Paris, France, 2016.

12. Burns, L.D. Sustainable mobility: A vision of our transport future. Nature 2013, 497, 181. [CrossRef] [PubMed]

13. Bakker, S.; Trip, J.J. Policy options to support the adoption of electric vehicles in the urban environment. Transp. Res. Part D Transp. Environ. Sci. Technol. 2013, 25, 18-23. [CrossRef]

14. Han, S.; Zhang, B.; Sun, X.; Han, S.; Höök, M. China's Energy Transition in the Power and Transport Sectors from a Substitution Perspective. Energies 2017, 10, 600. [CrossRef]

15. Ustun, T.S.; Zayegh, A.; Ozansoy, C. Electric Vehicle Potential in Australia: Its Impact on Smartgrids. IEEE Ind. Electron. Mag. 2013, 7, 15-25. [CrossRef]

16. Weiss, M.; Patel, M.K.; Junginger, M.; Perujo, A.; Bonnel, P.; van Grootveld, G. On the electrification of road transport-Learning rates and price forecasts for hybrid-electric and battery-electric vehicles. Energy Policy 2012, 48, 374-393. [CrossRef]

17. Gao, H.O.; Kitirattragarn, V. Taxi owners' buying preferences of hybrid-electric vehicles and their implications for emissions in New York City. Transp. Res. Part A Policy Pract. 2008, 42, 1064-1073. [CrossRef]

18. Huo, H.; Zhang, Q.; Liu, F.; He, K. Climate and environmental effects of electric vehicles versus compressed natural gas vehicles in China: A life-cycle analysis at provincial level. Environ. Sci. Technol. 2013, 47, 1711-1718. [CrossRef] 
19. Thomas, V.J.; Maine, E. Market entry strategies for electric vehicle start-ups in the automotive industry-Lessons from Tesla Motors. J. Clean. Prod. 2019, 235, 653-663. [CrossRef]

20. Merchant, A.; Rose, G.M.J.J.O.B.R. Effects of advertising-evoked vicarious nostalgia on brand heritage. J. Bus. Res. 2013, 66, 2619-2625. [CrossRef]

21. Sohu. Creating New Value Is Controversial? At Least These Four Points Upload That the Unified Vehicle Enterprises Can Not Catch Up with the New Forces. Available online: https:/ / www.sohu.com/a/231730122_448326 (accessed on 7 January 2022).

22. Peters, A.; Gutscher, H.; Scholz, R. Behaviour. Psychological determinants of fuel consumption of purchased new cars. Transp. Res. Part F Traffic Psychol. Behav. 2011, 14, 229-239. [CrossRef]

23. Ewing, G.O.; Sarigöllü, E. Environment. Car fuel-type choice under travel demand management and economic incentives. Transp. Res. Part D Transp. Environ. 1998, 3, 429-444. [CrossRef]

24. Lane, B.; Potter, S. The adoption of cleaner vehicles in the UK: Exploring the consumer attitude-action gap. J. Clean. Prod. 2007, 15, 1085-1092. [CrossRef]

25. Krupa, J.S.; Rizzo, D.M.; Eppstein, M.J.; Brad Lanute, D.; Gaalema, D.E.; Lakkaraju, K.; Warrender, C.E. Analysis of a consumer survey on plug-in hybrid electric vehicles. Transp. Res. Part A Policy Pract. 2014, 64, 14-31. [CrossRef]

26. Franke, T.; Krems, J.F. What drives range preferences in electric vehicle users? Transp. Policy 2013, 30, 56-62. [CrossRef]

27. Carley, S.; Krause, R.M.; Lane, B.W.; Graham, J.D. Environment. Intent to purchase a plug-in electric vehicle: A survey of early impressions in large US cites. Transp. Res. Part D Transp. Environ. 2013, 18, 39-45. [CrossRef]

28. Koetse, M.J.; Hoen, A. Economics, E. Preferences for alternative fuel vehicles of company car drivers. Resour. Energy Econ. 2014, 37, 279-301. [CrossRef]

29. Zhang, Y.; Yu, Y.; Li, T.; Zou, B. Analyzing Chinese consumers' perception for biofuels implementation: The private vehicles owner's investigating in Nanjing. Renew. Sustain. Energy Rev. 2011, 15, 2299-2309. [CrossRef]

30. Ajzen, I.; Fishbein, M. Understanding Attitudes and Predicting Social Behavior; Prentic Hall: Englewood Cliffs, NY, USA, 1980.

31. Fishbein, M.; Ajzen, I. Belief, attitude, intention, and behavior: An introduction to theory and research. Philos. Rhetor. 1977, 10.

32. Ajzen, I. From intentions to actions: A theory of planned behavior. In Action Control; Springer: Berlin, Germany, 1985; pp. 11-39.

33. Davis, F.D.; Bagozzi, R.P.; Warshaw, P.R. User acceptance of computer technology: A comparison of two theoretical models. Manag. Sci. 1989, 35, 982-1003. [CrossRef]

34. Jin, N.P.; Lee, S.; Lee, H. The Effect of Experience Quality on Perceived Value, Satisfaction, Image and Behavioral Intention of Water Park Patrons: New versus Repeat Visitors. Int. J. Tour. Res. 2015, 17, 82-95. [CrossRef]

35. Orbell, S.; Crombie, I.; Johnston, G. Social cognition and social structure in the prediction of cervical screening uptake. Br. J. Health Psychol. 1996, 1, 35-50. [CrossRef]

36. Tsujikawa, N.; Tsuchida, S.; Shiotani, T. Changes in the Factors Influencing Public Acceptance of Nuclear Power Generation in Japan Since the 2011 Fukushima Daiichi Nuclear Disaster. Risk Anal. 2016, 36, 98-113. [CrossRef] [PubMed]

37. Potoglou, D.; Kanaroglou, P.S. Household demand and willingness to pay for clean vehicles. Transp. Res. Part D Transp. Environ. 2007, 12, 264-274. [CrossRef]

38. Wang, S.; Fan, J.; Zhao, D.; Yang, S.; Fu, Y. Predicting consumers' intention to adopt hybrid electric vehicles: Using an extended version of the theory of planned behavior model. Transportation 2014, 43, 123-143. [CrossRef]

39. Morganti, E.; Browne, M. Technical and operational obstacles to the adoption of electric vans in France and the UK: An operator perspective. Transp. Policy 2018, 63, 90-97. [CrossRef]

40. Tu, J.-C.; Yang, C. Key Factors Influencing Consumers' Purchase of Electric Vehicles. Sustainability 2019, 11, 3863. [CrossRef]

41. Zhang, X.; Wang, K.; Hao, Y.; Fan, J.-L.; Wei, Y.-M. The impact of government policy on preference for NEVs: The evidence from China. Energy Policy 2013, 61, 382-393. [CrossRef]

42. Dunn, M.G.; Murphy, P.E.; Skelly, G.U. Research note: The influence of perceived risk on brand preference for supermarket products. J. Retail. 1986, 62, 204-216.

43. She, Z.-Y.; She, Z.-Y.; Sun, Q.; Ma, J.-J.; Xie; B.-C. What are the barriers to widespread adoption of battery electric vehicles? A survey of public perception in Tianjin, China. Transp. Policy 2017, 56, 29-40. [CrossRef]

44. Lim, M.K.; Mak, H.-Y.; Rong, Y. Toward Mass Adoption of Electric Vehicles: Impact of the Range and Resale Anxieties. Manuf. Serv. Oper. Manag. 2015, 17, 101-119. [CrossRef]

45. Jensen, A.F.; Cherchi, E.; Mabit, S.L. On the stability of preferences and attitudes before and after experiencing an electric vehicle. Transp. Res. Part D Transp. Environ. 2013, 25, 24-32. [CrossRef]

46. Graham-Rowe, E.; Gardner, B.; Abraham, C.; Skippon, S.; Dittmar, H.; Hutchins, R.; Stannard, J. Mainstream consumers driving plug-in battery-electric and plug-in hybrid electric cars: A qualitative analysis of responses and evaluations. Transp. Res. Part A Policy Pract. 2012, 46, 140-153. [CrossRef]

47. Wang, S.; Wang, J.; Lin, S.; Li, J. Public perceptions and acceptance of nuclear energy in China: The role of public knowledge, perceived benefit, perceived risk and public engagement. Energy Policy 2019, 126, 352-360. [CrossRef]

48. Yang, J.Y.; Chou, L.D.; Chang, Y.J. Electric-Vehicle Navigation System Based on Power Consumption. IEEE Trans. Veh. Technol. 2016, 65, 5930-5943. [CrossRef]

49. Liu, H.; Yin, W.; Yuan, X.; Niu, M. Reserving Charging Decision-Making Model and Route Plan for Electric Vehicles Considering Information of Traffic and Charging Station. Sustainability 2018, 10, 1324. [CrossRef] 
50. Egbue, O.; Long, S. Barriers to widespread adoption of electric vehicles: An analysis of consumer attitudes and perceptions. Energy Policy 2012, 48, 717-729. [CrossRef]

51. Dean, H.D. Brand Endorsement, Popularity, and Event Sponsorship as Advertising Cues Affecting Consumer Pre-Purchase Attitudes. J. Advert. 1999, 28, 1-12. [CrossRef]

52. Fireworker, R.B.; Friedman, H.H. The Effects of endorsements on product evaluation. Decis. Sci. 1977, 8, $576-583$.

53. Friedman, H.H.; Friedman, L. Endorser Effectiveness by Product Type. J. Advert. Res. 1979, 19, 63-71.

54. Freiden, J.B. Advertising spokesperson effects: An examination of endorser type and gender on two audiences. J. Advert. Res. 1984, 24, 33-41.

55. Feng, J.; Wang, K.Y.; Peracchio, L.A. How Third-Party Organization (Tpo) Endorsement Advertising Works: Do Consumers Perceive Tpo Endorsement As Signals of Quality? Adv. Consum. Res. 2008, 35, 616-623.

56. Wang, A. Integrating and Comparing Others' Opinions: The Effects of Third-Party Endorsements on Online Purchasing. J. Website Promot. 2005, 1, 105-129. [CrossRef]

57. Wakefield, R.L.; Whitten, D. Examining User Perceptions of Third-Party Organization Credibility and Trust in an E-Retailer. J. Organ. End User Comput. 2006, 18, 1-19. [CrossRef]

58. Tang, W.; Sun, Y. Who will "endorse" the brand. China Brand Anti-Count. 2007, 000, 42-44.

59. Hartmann, M.; Klink, J.; Simons, J. Cause related marketing in the German retail sector: Exploring the role of consumers' trust. Food Policy 2015, 52, 108-114. [CrossRef]

60. Xie, Y.; Batra, R.; Peng, S. An Extended Model of Preference Formation between Global and Local Brands: The Roles of Identity Expressiveness, Trust, and Affect. J. Int. Mark. 2015, 23, 50-71. [CrossRef]

61. Lassoued, R.; Hobbs, J.E. Consumer confidence in credence attributes: The role of brand trust. Food Policy 2015, 52, 99-107. [CrossRef]

62. Zhao, W.; Sun, R.; Kakuda, N. Institutionalized place branding strategy, interfirm trust, and place branding performance: Evidence from China. J. Bus. Res. 2017, 78, 261-267. [CrossRef]

63. Han, S.H.; Nguyen, B.; Lee, T.J. Consumer-based chain restaurant brand equity, brand reputation, and brand trust. Int. J. Hosp. Manag. 2015, 50, 84-93. [CrossRef]

64. Laroche, M.; Habibi, M.R.; Richard, M.-O.; Sankaranarayanan, R. The effects of social media based brand communities on brand community markers, value creation practices, brand trust and brand loyalty. Comput. Hum. Behav. 2012, 28, 1755-1767. [CrossRef]

65. Pentina, I.; Zhang, L.; Basmanova, O. Antecedents and consequences of trust in a social media brand: A cross-cultural study of Twitter. Comput. Hum. Behav. 2013, 29, 1546-1555. [CrossRef]

66. Jin, S.V.; Phua, J. The moderating effect of computer users' autotelic need for touch on brand trust, perceived brand excitement, and brand placement awareness in haptic games and in-game advertising (IGA). Comput. Hum. Behav. 2015, 43, 58-67. [CrossRef]

67. Irwin, A.; Wynne, B. Misunderstanding Science? The Public Reconstruction of Science and Technology; Cambridge University Press: Cambridge, UK, 2003.

68. Flynn, R. Risk and the public acceptance of new technologies. In Risk and the Public Acceptance of New Technologies; Springer: London, UK, 2007; pp. 1-23.

69. Peters, A.; Dütschke, E. How do consumers perceive electric vehicles? A comparison of German consumer groups. J. Environ. Policy Plan. 2014, 16, 359-377. [CrossRef]

70. Gallagher, K.S.; Muehlegger, E. Giving green to get green? Incentives and consumer adoption of hybrid vehicle technology. J. Environ. Econ. Manag. 2011, 61, 1-15. [CrossRef]

71. Chandra, A.; Gulati, S.; Kandlikar, M. Green drivers or free riders? An analysis of tax rebates for hybrid vehicles. J. Environ. Econ. Manag. 2010, 60, 78-93. [CrossRef]

72. Li, G. The rise of great powers and brand endorsement. Text. Appar. Wkly. 2013, 13, 48.

73. Keillor, B.D.; Hult, G. A five-country study of national identity: Implications for international marketing research and practice. Int. Mark. Rev. 1999, 16, 65-84. [CrossRef]

74. He, J.; Zhu, L.; Huang, H. The Effectiveness of National Image Strategy:A Research on How National Image Influences the Attitude towards "Made in China" from the Perspective of British and American Consumers. J. East China Norm. Univ. Humanit. Soc. Sci. 2017, 49, 124-135.

75. De Ona, J.; De Ona, R.; Eboli, L.; Forciniti, C.; Mazzulla, G. Transit passengers' behavioural intentions: The influence of service quality and customer satisfaction. Transportmetrica 2016, 12, 385-412.

76. Dan, J.K.; Ferrin, D.L.; Rao, H.R. Trust and Satisfaction, Two Stepping Stones for Successful E-Commerce Relationships: A Longitudinal Exploration. Inf. Syst. Res. 2009, 20, 237-257.

77. Wang, S.; Jing, W.; Li, J.; Wang, J.; Liang, L. Policy implications for promoting the adoption of electric vehicles: Do consumer's knowledge, perceived risk and financial incentive policy matter? Transp. Res. Part A Policy Pract. 2018, 117, 58-69. [CrossRef]

78. Han, H.; Yu, J.; Kim, W. An electric airplane: Assessing the effect of travelers' perceived risk, attitude, and new product knowledge. J. Air Transp. Manag. 2019, 78, 33-42. [CrossRef]

79. Lassoued, R.; Hobbs, J.E. The Determinants of Consumer Confidence in Credence Attributes:Trust in the Food System and in Brands. In Proceedings of the 2014 AAEA/EAAE/CAES Joint Symposium: Social Networks, Social Media and the Economics of Food, Montreal, BC, Canada, 29-30 May 2014. 
80. Spagnolli, A.; Guardigli, E.; Orso, V.; Varotto, A.; Gamberini, L. Measuring User Acceptance of Wearable Symbiotic Devices: Validation Study Across Application Scenarios. In Proceedings of the International Workshop on Symbiotic Interaction, Helsinki, Finland, 30-31 October 2014.

81. Lv, F. Investigation and analysis of national identity of college students in Beijing. CASS J. Political Sci. 2010, $21,58-64$.

82. Jackson, D.L. Revisiting Sample Size and Number of Parameter Estimates: Some Support for the N:q Hypothesis. Struct. Equ. Model. A Multidiscip. J. 2003, 10, 128-141. [CrossRef]

83. Norusis, M.J. SPSS for Windows: Base System User's Guide, Release 5.0; SPSS Incorporated: Chicago, IL, USA, 1992.

84. Kaiser, H.F. An index of factorial simplicity. Psychometrika 1974, 39, 31-36. [CrossRef]

85. Harman, H. Modern Factor Analysis; University of Chicago Press: Chicago, IL, USA, 1960.

86. Kohli, A.K.; Shervani, T.A.; Challagalla, G.N. Learning and performance orientation of salespeople: The role of supervisors. J. Mark. Res. 1998, 35, 263-274. [CrossRef]

87. Fornell, C.; Larcker, D.F. Evaluating Structural Equation Models with Unobservable Variables and Measurement Error. J. Mark. Res. 2018, 18, 39-50. [CrossRef]

88. Huang, X.; Ge, J. Electric vehicle development in Beijing: An analysis of consumer purchase intention. J. Clean. Prod. 2019, 216, 361-372. [CrossRef]

89. Caulfield, B.; Farrell, S.; McMahon, B. Examining individuals preferences for hybrid electric and alternatively fuelled vehicles. Transp. Policy 2010, 17, 381-387. [CrossRef]

90. Muslim, N.H.; Keyvanfar, A.; Shafaghat, A.; Abdullahi, M.a.M.; Khorami, M. Green driver: Travel behaviors revisited on fuel saving and less emission. Sustainability 2018, 10, 325. [CrossRef]

91. Kim, M.-K.; Oh, J.; Park, J.-H.; Joo, C. Perceived value and adoption intention for electric vehicles in Korea: Moderating effects of environmental traits and government supports. Energy 2018, 159, 799-809. [CrossRef]

92. Yang, C.; Tu, J.C.; Jiang, Q. The Influential Factors of Consumers' Sustainable Consumption: A Case on Electric Vehicles in China. Sustainability 2020, 12, 3496. [CrossRef]

93. Bunce, L.; Harris, M.; Burgess, M. Charge up then charge out? Drivers' perceptions and experiences of electric vehicles in the UK. Transp. Res. Part A Policy Pract. 2014, 59, 278-287. [CrossRef]

94. Melliger, M.A.; Van, V.O.P.R.; Heikki, L. Anxiety vs reality-Sufficiency of battery electric vehicle range in Switzerland and Finland. Transp. Res. Part D Transp. Environ. 2018, 65, 101-115. [CrossRef]

95. Erdem, T.; Swait, J. Brand credibility, brand consideration, and choice. J. Consum. Res. 2004, 31, 191-198. [CrossRef] 